\title{
Prioritizing Competitive Strategies in Iranian SME's Based on AHP Approach in Severe Economic Sanctions
}

\author{
Mostafa Hosseinzadeh ${ }^{1}$, Seyed Mahdi Vesal ${ }^{1}$, Reza Shamsaddini ${ }^{2}$, Azadeh Kamel ${ }^{3}$ \\ ${ }^{1}$ MBA, Strategy, Department of Management, University of Nooretouba, Tehran, Iran \\ ${ }^{2}$ Department of Management, Vali-e-asr University of Rafsanjan, Rafsanjan, Iran \\ ${ }^{3}$ Master of e-business management, Industrial Management Institute (IMI), Tehran, Iran \\ Correspondence: Mostafa Hosseinzadeh, Department of Management, University of Nooretouba, Tehran, Iran. \\ Tel: 98-911-100-6570. E-mail: mostafa_hosseinzadeh.amiri@yahoo.com
}

Received: April 18, 2013

Accepted: June 5, 2013

Online Published: July 16, 2013

doi:10.5539/ijbm.v8n16p48

URL: http://dx.doi.org/10.5539/ijbm.v8n16p48

\begin{abstract}
Hard and compressed competition, constant change and instable and environmental uncertainty, and creating new needs and in consequence of creation of new markets, rapid change in technology and need for constant learning in organizations and personnel and... are of characteristics of today's market. Besides changing the strategic management of e-commerce is changing many other industries. The topic of this research is "review and prioritizing of competitive strategies in SME's in AHP method". The main question to the presence research, is that according to the source and budget limitations that no organization can deploy those competitive strategies, so how best SME's, can use competitive strategy according to the present time that would fit best in the hard conditions of the market? Doing this work, we have used Michael Porter's view about competitive strategy. This has made of Cost Leadership, Focus, and Differentiation. Statistic research, employers of SME's and survey-applied research method were used in this research. Data collection entails 63 Iranian SME's were as the sample for this study. After performing the research, the results reveal that the best strategy among competitive strategies for Iranian SME's is the Cost Leadership Strategy.
\end{abstract}

Keywords: competitive strategies, prioritizing, Analytic Hierarchy Process (AHP), SME's

\section{Introduction}

Rapid and major changes in the current market environment emphasize on the necessity and importance of identifying, survey and prioritizing competitive strategies, and any organization which would go to a higher level than its clients' expectations and succeed in the business world has no other way except following such strategy. In manufacturing organizations which generally need huge investigation and profitability and return on investment was the major problem and organization had to go to a higher level of survival and effort durability and focus on Profit Orientation and Survival Orientation (RamezaniTehrani, 2009).

Business strategy might include geographic expansion, diversification, acquisition, product development, market penetration, staff rationalization, divestment, liquidation and joint ventures. This planned series of action for achieving the long term goals (Suliyanto, et al., 2010).

Two main changes has been change the way of manufacturing SME operate. These are Globalization and technological innovations. These have made the environment more competitive and it has made SME's exposure various risks of loosing competitiveness and profitability. The essential thing for using these new two types of risk could continue to effectively and efficiently operate at the same time getting the competitive advantage and ensure their profitability (Turgay \& Karibov, 2008).

Iran has imposed severe economic sanctions against Iranian companies in the unusual and abnormal situations, and the button has been unjust and unfair. Iranian companies in this situation needs to be reviewed and prioritized competitive strategies. In this study, we have made "SMEs" as companies employing not more than 200 employees.

The researches have indicated that in highly competitive market. SME usually are successful if they customized solution for customers. Many of SME has started their activities from the family business or their relatives (Park, et al., 2008). The main unit that has emphasized role in developing strength and zonal Integration is SME that 
means Small and Medium-sized Enterprise (Kira, 2013).

Organizations, including SME's, to save and survive in such uncertain market refer to survey, identify and prioritize the goals and competitive strategies so that achieve more competitive advantages and useful among the contenders. Among the most model of strategies, Porter's competitive strategy is the best and well known strategy that has introduced the strategies as cost leadership, concentration and differentiation as the identify of the model.

\section{Competitive Strategies}

Competitiveness is not a readily measurable concept. Some Organization such as organization for Economic Cooperation and Development (OECD) suppose that the meaning of competitiveness entails fair competition, trade performance and sustainable economic growth (Sirikrai, 2007).

As the talks about Porter (1980), his view is made three general strategies: 1) Differentiation, recommend something new and better than before to the customer by the competitors. That means the presenting of some services should be unique or the service has the best function. 2) Cost advantages (low cost), by this view the competitors should think and find the best kind of strategy about entire production. That means, the total cost of goods should be cheaper than by the other competitor's price, but the quality should be changed and fix. 3) Focus, this part mainly works on specific target market. This strategy is just for product-service that has special segment and all its provide benefit and function that are to segment (Suliyanto, et al., 2010). Generic strategy is one of the most popular business strategies that are based on getting competitive environment and the business's capabilities relative to other competitors. Researches represent the link between organizational characteristics and the generic business strategy of cost and differentiation is a recent development (Turgay \& Karibov, 2008). Porter's model for competitive strategies provides a general framework for understanding how firms gain and maintain competitive advantages (Mo Koo, et al., 2004).

The main role of competitive strategy is to connect companies with their environment. Although some of clear environment is very broad covering, social forces is just like as economic forces, and the main aspects of this environment are in the field of companies competition. Industrial structure has a powerful influence in determining the rules of the game competition as well as the strategies powerfully and easily able to use for companies (Suliyanto, et al., 2010).

In low cost strategy, the main work is to set out business for becoming the low cost player in its industry. Low cost strategy can be achieved by pursuing of economies of scale, proprietary technology, preferential accessing to raw materials and other factors. According to differentiation strategy a business must be unique in its industry whether the goods or services in the way it operates. By pursuing differentiation strategy, businesses are often able to set premium price for their unique products or services. Regard to focus strategy it has two variant which are (a) cost focus: business try a cost advantage in its target market; and (b) differentiation focus: business try differentiation in its target market (Porter, 1985; cited by: Huu Le \& Nhu, 2009).

The Porter 3 Generic Strategies, it has strategic target on its vertical axis that can be shared into two different parts: Industry wide multi - segment and particular segment. In the horizontal axis is Strategic Advantage that can be divided into two positions that first is uniqueness perceived by Customer and Low-Cost Position (Baroto, et al., 2012). 


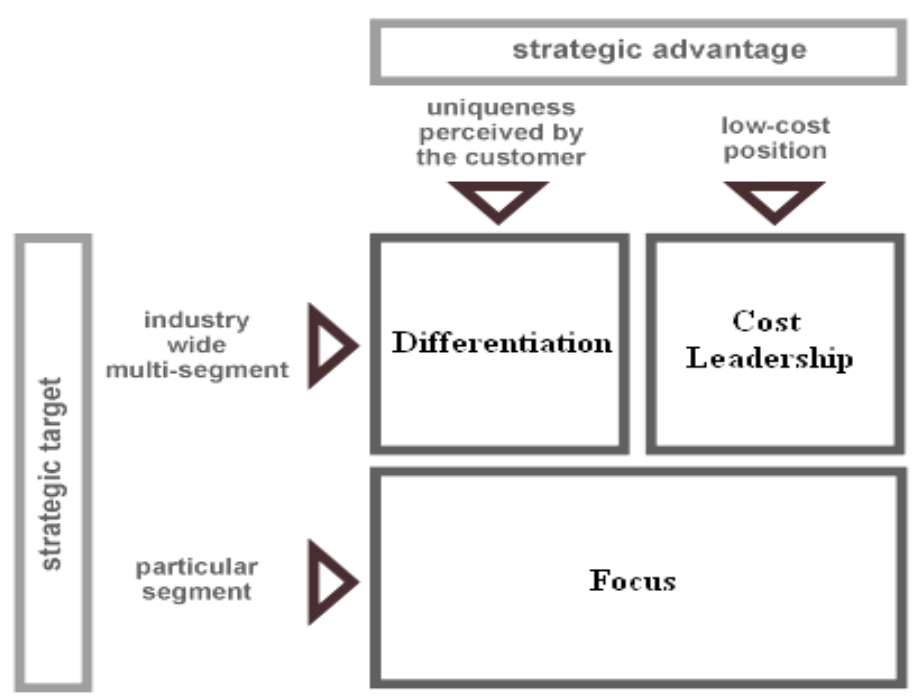

Figure1. Porter's three generic strategies (Baroto, et al., 2012)

One of the requires of Cost leadership is a strong focus on the supply side as opposed to the demand side of the market (Day \& Wendley, 1988). A business that pursues cost leadership strategy achieves a low-cost position by emphasizing on "aggressive construction of efficient-scale facilities, vigorous pursuit of cost reductions from experience, tight cost and overhead control, avoidance of marginal customer accounts, and cost minimization in areas like research and development (R\&D), services, sales force, advertising, etc". The generic of differentiation strategy involves creating a market position that is supposed as being unique industry-wide and that is sustainable over the long period (Porter, 1980). Some differentiation is the base upon design or brand image, distribution, and so forth (Frambach et. al, 2003; cited by: Baroto, et al., 2012).

\section{Methodology}

The Analytic Hierarchy Process (AHP) introduced by (Saaty, 1980). Since then it has used in many applications and in a different variant. Multi-criteria AHP method belongs to Multiple Criteria Decision Making tools (MCDM) (Hudymáčová, et al., 2010). The AHP is one of the most well-known decision-making methods to assist in the complex task of reaching the best decision from a set of possible criteria. The AHP provides a mathematically based application and proven process for prioritization of alternatives (Chien-Wen Chen, et al., 2011). The AHP uses a principle of hierarchic composition to derive composite priorities of alternatives with respect to multiple criteria from their priorities with respect to each criterion. It consists of multiplying each priority of an alternative by the priority of its corresponding criterion and adding over all the criteria to obtain the overall priority of that alternative. This is perhaps the simplest way for composing priorities (Saaty, 2003). The AHP is a well-known multi-criteria aggregation model based on pair-wise comparison matrices at two fundamental levels: the lower level encodes pair-wise comparison matrices between alternatives (one such matrix for each criterion) and the higher level encodes a single pair-wise comparison matrix between criteria (Bortot \& Pereira, 2011). One of the advantages of AHP is to help decision makers can be work on both side of quantitative and qualitative view's of problem. Basically, It can solves complex problems by decomposing the structure of a problem into hierarchies and the users then make pair-wise comparison judgments as to importance or preference to develop priorities in each part (Gerdsri \& Kocaoglu, 2007). These are represented in term of pair-wise comparisons of items on a given level of the hierarchy with respect to their impact on the next higher level. According to pair-wise comparisons, the following set of number (Table 1.) each of ehich is an average random consistency index. These index indicate the relative importance of item which another one are in meeting a goal or criterion and Each one of the pair-wise comparisons shows an estimate of the ratio of the weights of the two criteria being compared (Tahriri, et al., 2008). 


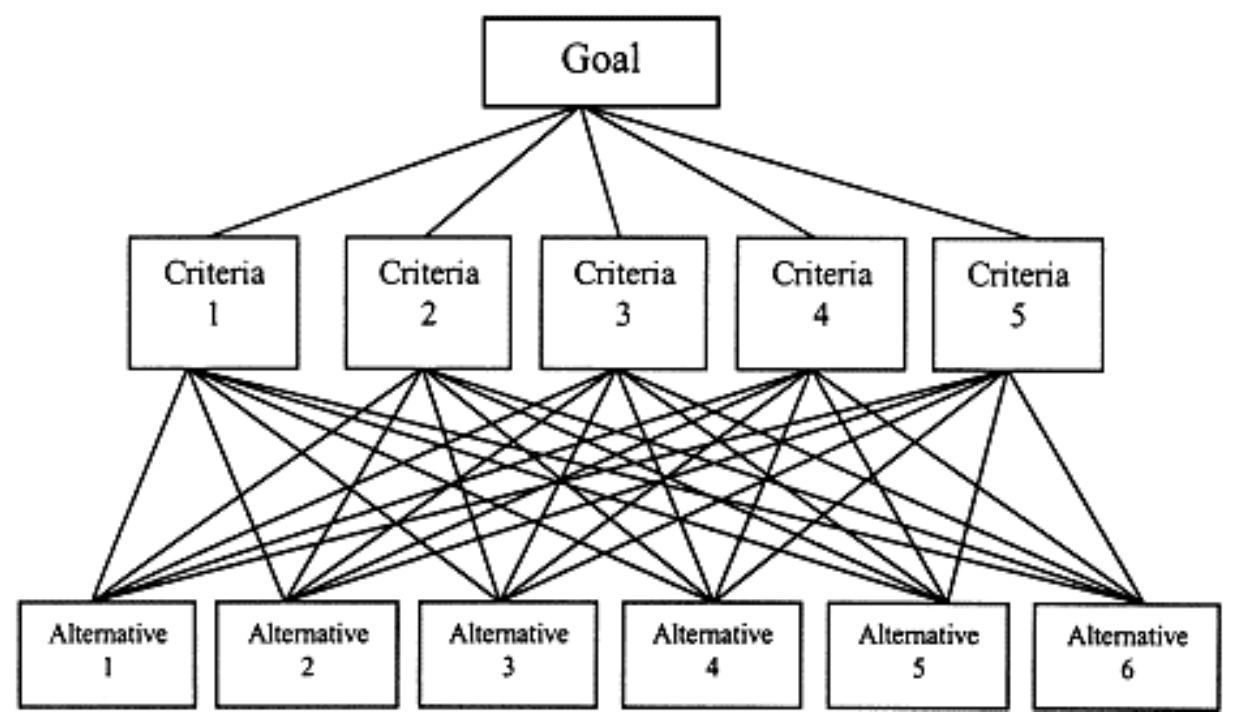

Figure 2. Analytical Hierarchy Process (AHP) model

AHP is based on comparing $n$ objects in pairs according to their relative weights. In AHP, the ratio scales for pair-wise comparison range from 1 to 9 representing judgment entries where 1 is equally important and 9 is absolutely more important (Alam \& Shrabonti, 2002). As usual comparisons were done by standard APH questionnaires and the result converts to paired comparison matrices. In order to combine different people's ideas geometric mean approach were used. The stability of this questionnaire was based on inconsistency rate which had to be less than 0.1 .

Table 1. Pair-wise comparison scale for AHP preferences (Saaty, 1980, 1990, 1991)

\begin{tabular}{cc}
\hline Numerical rating & Verbal judgments of preferences \\
\hline 9 & Extremely preferred \\
8 & Very strongly to extremely \\
7 & Very strongly preferred \\
6 & Strongly to very strongly \\
5 & Strongly preferred \\
4 & Moderately to strongly \\
3 & Moderately to preferred \\
2 & Equally to Moderately \\
1 & Equally preferred \\
\hline
\end{tabular}

In the hierarchy structure, factors of each level are marked as: $A_{1}, A_{2}, \ldots, A_{n}$. Based on the index of the upper level, weights of factors, $w_{1}, w_{2}, \ldots, w_{n}$ are to be determined. The relative importance of $a_{i}$ and $a_{j}$ is shown as $a_{i j}$, the pair-wise comparison matrix of factors $A_{1}, A_{2}, \ldots, A_{n}$ as $A=\left[a_{i j}\right]$. In this matrix, the element $a_{i j}=1 / a_{j i}$ and thus, when $\mathrm{i}=\mathrm{j}, \mathrm{a}_{\mathrm{ij}}=1$. The value of $\mathrm{w}_{\mathrm{i}}$ may vary from 1 to 9 , and $1 / 1$ indicates equal importance while $9 / 1$ indicates extreme or absolute importance.

The consistency index of a matrix of comparisons is given by the formulas (1) and (2). The consistency ratio (C.R.) is obtained by comparing the C.I. with the appropriate one of the following set of numbers (see Table 1) each of which is an average random consistency index (R.I.) derived from a sample of randomly generated reciprocal matrices using the scale $1 / 9,1 / 8, \ldots, 8,9$. If it is not less than 0.10 , study the problem and revise the judgments (Saaty \& Vargas, 1990; Chang \& Huang, 2006; Lee et al. 2009).

$$
\begin{gathered}
C R=\frac{C I}{R I} \\
C I=\left(\lambda_{\max }-n\right) /(n-1)
\end{gathered}
$$




\section{Analysis and Results}

In this research, we study 63 Iranian SME's. Field of these companies is Automobile and Steel Industry. Prioritizing was done upon AHP method based on Expert Choice software, in which the analysis results are as follows:

1) Cost leadership with importance: 0.652

2) Focus (Concentration) with importance: 0.242

3) Differentiation with importance: 0.106

synthesis with respect to:

Goal: prioritizing

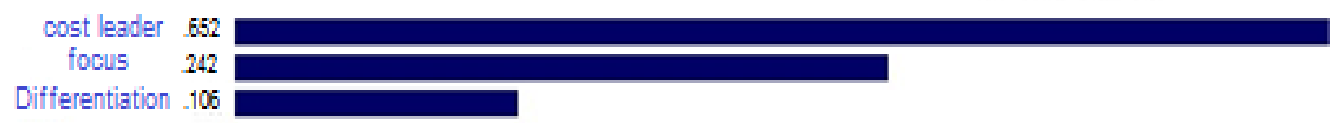

Figure 3. The software output (rating scale)

The results are as following items which is based on the SME's competitive strategy prioritizing method:

1) Cost leadership;

2) Focus;

3) Differentiation.

Thus, the best competitive strategy for Iranian SME's in Severe Economic Sanctions is Cost leadership strategy. In this research, the questionnaires were analyzed using Expert Choice software.

\section{Conclusion}

With respect to the uncertain and agitated environment of nowadays, companies, specially the manufacturing companies inevitably formulate a coherent plan for dealing with various problems which itself does require identifying and prioritizing competitive strategies, that Iranian SME's have already been on it. Global competition has made the analysis of competitiveness a vital component of strategic planning.

This study's goal is to investigate of how Iranian SME's react with economic sanctions and for assessing this effect of competitive strategies including low cost strategy, differentiation strategy and focus strategy in such conditions.

This paper applies an AHP model to analyze the competitive strategies of SME's in Iran. In this paper, we are prioritizing the AHP method of competitive strategy which the software analysis output is as follows:

1) Cost leadership;

2) Focus;

3) Differentiation.

Therefore the best competitive strategy in Severe Economic Sanctions for Iranian SME's is the cost leadership strategy. In terms of practical contributions, this study shows how the competitive strategies can be measured and improved. Results of this study therefore, offer to select and focus to cost leadership as competitive strategy based on Porter's model.

\section{References}

Alex, R. K. (2013). Determinants of Financing Constraints in East African Countries' SMEs. International Journal of Business and Management, 8(8), 49-68. http://dx.doi.org/10.5539/ijbm.v8n8p49

Bortot, S., \& Marques Pereira, R. A. (2011). Modeling Inconsistency in the AHP through Choquet Integration. The $11^{\text {th }}$ International Symposium on the Analytic Hierarchy Process (ISAHP), Sorrento (Naples), Italy.

Chang, H., \& Huang, W. (2006). Application of a quantification SWOT analytical method. Mathematical and Computer Modeling, 43, 158-169. http://dx.doi.org/10.1016/j.mcm.2005.08.016

Chul, M. K., Chang, E. K., \& Kichan, N. (2004). An Examination of Porter's Competitive Strategies in Electronic 
Virtual Markets: A Comparison of Two On-line Business Models. International Journal of Electronic Commerce, 9(1), 163-180.

Day, G., \& Wensley, R. (1998). Assessing advantage: A framework for diagnosing competitive superiority. Journal of Marketing, 52, 1-20. http://dx.doi.org/10.2307/1251261

Frambach, R. T., Prabhu, J., \& Verhallen, T. (2003). The Influence of Business Strategy on New Product Activity: The Role of Market Orientation. International Journal of Research in Marketing, 20(4), 377-397. http://dx.doi.org/10.1016/j.jiresmar.2003.03.003

Hudymáčová, M., Benková, M., Pócsová, J., \& Škovránek, T. (2010). Supplier Selection Based on Multi-Criterial AHP Method. Acta Montanistica Slovaca Ročnik, 15(3), 249-255.

Huu, L., \& Nguyen, N. (2009). Do, Food Retail Competitive Strategy in Recession Economy: A Case of Successful Foreign Discount Stores in Finland. International Journal of Business and Management, 4(6), 44-55.

Ji-Yeu, P., Rosslin John, R., Chang-Hwa, H., Sang-Soo, Y., \& Tai-hoon, K. (2008). IT Security Strategies for SME's. International Journal of Software Engineering and Its Applications, 2(3), 91-98.

Lee, J., Kang, S., \& Kim, C. (2009). Software architecture evaluation methods based on cost benefit analysis and quantitative decision making. Empirical Software Engineering, 14(4), 453-475. http://dx.doi.org/10.1007/s10664-008-9094-4

Mas, B. B., Muhammad Madi, B. A., \& Wan, H. L. (2012). Hybrid Strategy: A New Strategy for Competitive Advantage. International Journal of Business and Management, 7(20), 120-133.

Porter, M. (1980). Techniques for analyzing industries and competitors, Competitive Strategy. New York: Free Press.

Porter, M. E. (1985). The Competitive Advantage: Creating and Sustaining Superior Performance. N.Y.: Free Press.

Ramezani, T. B. (2009). Switching Focus in New Business Enterprise: From a Survival to a Profit Orientation. Master of Applied Science in Management Science's thesis, University of Waterloo, Canada.

Saaty, T. L. (1980). The Analytic Hierarchy Process. New York: McGraw-Hill.

Saaty, T. L. (1990). How to make a decision: the analytic hierarchy process. European Journal of Operational Research, 48, 9-26. http://dx.doi.org/10.1016/0377-2217(90)90057-I

Saaty, T. L. (2003). Decision-making with the AHP: Why is the principal eigenvector necessary. European Journal of Operational Research, 145, 85-91. http://dx.doi.org/10.1016/S0377-2217(02)00227-8

Saaty, T. L., \& Kearns, K. P. (1991). Analytical planning: the organization of systems. The analytic hierarchy process series, 4. USA: RWS Publications Pittsburgh.

Saaty, T. L., \& Vargas, L. G. (1990). Models, Methods, Concepts \& Applications of the Analytic Hierarchy Process. Boston: Kluwer Academic Publishers.

Sirikrai, S. (2007). Competitiveness Analysis: An AHP Approach for the Automotive Components Industry in Thailand. Thammasat Review, 12(1), 85-115.

Suliyanto, W. S., \& Novandari, W. (2010). Competitive Strategy Model for Purbalingga Batik. Economic Journal of Emerging Marketing, 2(2), 169-185.

Tahriri, F., Osman, M. R., Ali, A., \& Yusuff, R. M. (2008). A Review of Supplier Selection Methods in Manufacturing Industries. Suranaree Journal of Science and Technology, 15(3), 201-208.

Turgay, T., \& Karibov, R. (2008). An Integrated e-Strategy Model for Increasing Competitive Performance of Manufacturing Small and Medium Sized Enterprises in Kazakhstan. Review of Social, Economic \& Business Studies, 9(10), 179-208.

\section{Copyrights}

Copyright for this article is retained by the author(s), with first publication rights granted to the journal.

This is an open-access article distributed under the terms and conditions of the Creative Commons Attribution license (http://creativecommons.org/licenses/by/3.0/). 